\title{
BISKUPI DYRRACHIONU W STRUKTURACH PATRIARCHATU KONSTANTYNOPOLA (VII-XI WIEK)
}

Początek średniowiecza przyniósł dotkliwe straty Kościołom chrześcijańskim na Wschodzie. Po najazdach muzułmanów poza obrębem władzy cesarza znalazły się starożytne patriarchaty w Aleksandrii, Antiochii i Jerozolimie. Potężne i wpływowe ośrodki kościelne w utraconych wschodnich prowincjach Cesarstwa zostały pozbawione swojego uprzywilejowanego statusu prawno-politycznego. Tylko patriarchat Konstantynopola, mimo utraty części biskupstw na Półwyspie Bałkańskim, potrafił utrzymać swoją dotychczasową rangę. Stołeczni hierarchowie byli silni nie tylko cesarską protekcją, ale również i własnym rosnącym kościelnym autorytetem, wspomaganym przez prężne zaplecze intelektualne. Wspólne działania cesarzy, patriarchów i podległego im duchowieństwa pozwoliły nie tylko utwierdzić autorytet kościelny Konstantynopola, postrzeganego w kategoriach Nowego Rzymu - Nowej Jerozolimy, ale również podkreślić wiarę w Boski patronat oraz moralne przywództwo prawowiernych chrześcijan ${ }^{1}$. Formy aktywności patriarchatu były zróżnicowane. Dostrzec tu można zarówno inicjatywy teologiczne, umiejętne wykorzystanie potencjału tych instytucji kościelnych, które przetrwały inwazje barbarzyńców w trudnym okresie Ciemnych Wieków czy działalność misyjna, która doprowadziła do znaczącego rozszerzenia zwierzchnictwa patriarchatu na nowe rozległe terytorialnie prowincje kościelne, powołane w Europie Wschodniej i Południowej po chrystianizacji tamtejszych monarchii barbarzyńskich w IX i X wieku.

Ważną rolę w procesie formowania się tej nowej średniowiecznej geografii kościelnej odegrały lokalne ośrodki położone zarówno na „starym” obszarze patriarchatu z V-VII w. (tj. diecezji Azji, Pontu i Tracji), jak i te usytuowane

* Dr hab. Jarosław Dudek, prof. UZ - profesor nadzwyczajny w Zakładzie Historii Średniowiecznej w Instytutcie Historii na Wydziale Humanistycznym Uniwersytetu Zielonogórskiego; e-mail: j.dudek@ih.uz.zgora.pl.

${ }^{1}$ Por. H.J. Widuch, Konstantynopol stolicq ekumenicznego patriarchatu 325-870, Katowice 1988, 39-65 (autor tego opracowania odnosi się do starszej literatury przedmiotu). A.P. K(azhdan) - A.M. T(albot), Constantinople, Patriarchat of, w: The Oxford Dictionary of Byzantium, I: AaroEski, ed. A.P. Kazhdan, New York - Oxford 1991, 520-523; G. Dagron, Chrześcijaństwo bizantyńskie od VII do polowy XI wieku, w: Biskupi, mnisi i cesarze: 610-1054, red. G. Dagron - P. Riché - A. Vauchez, thum. M. Żurowska (i in.), Warszawa 1999, 175-182. 
w zachodniej części Półwyspu Bałkańskiego, które zostały wyjęte spod jurysdykcji papieża i zgodnie z wolą cesarza Leona III Izauryjczyka (717-741) podporządkowane władzy patriarchy Konstantynopola ${ }^{2}$. Proces przejmowania nowych biskupstw utrwalano umieszczając je w wykazach metropolii i arcybiskupstw podlegających patriarchatowi. Nowych hierarchów zapraszano na kościelne synody, wpisując jednocześnie ich imiona na poczesne miejsce w gronie uczestników.

1. Dyrrachion. W formułę takiego postępowania wpisywała się postawa władz patriarchatu wobec biskupstwa w Dyrrachion (gr. Dyrrhachium czy Epidamnos, łac. Dyrrachium, wł. Durazzo, słow. Драч) czy Epidamnos ('E $\pi i ́ \delta \alpha \mu \nu \circ \varsigma$ ), obecnie albańskie Dürres. Miasto to było nie tylko najważniejszym portem Cesarstwa na wschodnim wybrzeżu Morza Jońskiego. Zamykało ono również od zachodu „Drogę Egnacką” (łac. Via Egnatia), będącą najdogodniejszym połączeniem lądowym Konstantynopola z Italią̧3. Jednak starożytne i średniowieczne dzieje Kościoła w Dyrrachion, nie przyciągnęły dotychczas uwagi badaczy $\mathrm{w}$ takim stopniu, jak ma to miejsce w wypadku innych metropolii usytuowanych na bałkańskich obrzeżach świata bizantyńskiego ${ }^{4}$. Aczkolwiek kościelne koneksje tego miasta wydają się nie ustępować tradycjom większości bałkańskich biskupstw. Swoimi korzeniami sięgająjeszcze do czasów wczesnochrześcijańskich w II, czy nawet I w., włącznie z po-

${ }^{2}$ Por. Regesten der Kaiserurkunden des Oströmischen Reiches von 565-1453, 1. Teil: Regesten von 565-1025, bearbeite von F. Dölger, München - Berlin 1924 (Reprint: Hildesheim 1976), nr 301; V. Grumel, L'annexion de l'Illyricum Oriental, de la Sicile et de la Calabrie au Patriarcat de Constantinople, RSR 39-40 (1952) 191-200; S. Turlej, Konflikt ikonoklastyczny a problem jurysdykcji nad Illyricum, w: Prawostawie, red. J. Drabina (= „Studia Religiologica” 29), Kraków 1996, 33-37.

${ }^{3}$ Por. К. Јиречек, Положај и прошлост града Драча, „Гласник Српског Географског Друштва" 1 (1912) nr 2, 182-191; A. Ducellier, Dyrr(h)achion, w: Lexikon des Mittelalters, III, München 1986, 1497-1500; T.E. G(regory), Dyrrachion, w: The Oxford Dictionary of Byzantium, I, s. 668; S. Rospond - W. Kowalenko, Drač, w: Stownik Starożytności Stowiańskich, t. 1: A-E, Wrocław - Warszawa 1961, 376-377; S. Rek, Dracz, w: Słownik Starożytności Słowiańskich, t. 8, cz. 1: Supplementy i indeksy, Wrocław - Warszawa 1991, 67-69.

${ }^{4}$ Chociaż należy dostrzec i docenić prace, które napisali: M. von Šufflay, Die Kirchenzustände im vortükischen Albanie. Die orthodoxe Durchbruchszone im katolischen Damme, w: Illyrischalbanische Forschungen, unter Mitwirkung von K. Jireček - M. von Šufflay (et al.), zusammengestellt von L. von Thallóczy, I, München 1916, 188-281; Th. Ippen, Alte Kirchen und Kirchenruinen in Albanien, ,Wissenschafliche Mitteinlungen aus Bosnien und der Herzegovina” 7 (1900) 231-242; 8 (1901) 131-144; tenże, Denkmäler verschiedener Altersstufen in Albanien, „Wissenschafliche Mitteinlungen aus Bosnien und der Herzegovina" 10 (1907) 3-70; H. \& H. Buschausen, Die Marienkirche von Apollonia in Albanien. Byzantiner, Normannen und Serben im Kampf um die Via Egnatia, Byzantina Vindobonensia 8, Wien 1976; G. Schramm, Anfänge des albanischen Christentums. Die frühe Bekehrung der Bessen und ihre langen Folgen, Rombach Wissenschaft, Reihe: Historiae 4, Freiburg im Breisgau 1994; A. Ducellier, La façade maritime de l'Albanie au Moyen Âge. Durazzo et Valona du XI au XVte siècle, Thessaloniki 1981. 
wołaniem się na pewne aspekty tradycji apostolskiej (np. Rz 15, 19). Żadne konkretne świadectwo nie przemawia za tym, by polityczne i etniczne niepokoje, charakterystyczne dla historii Bałkanów między V a VII w., przerwały funkcjonowanie tutejszych struktur eklezjalnych ${ }^{5}$. Należy jednak wskazać, iż zachowany materiał źródłowy dotyczący ośrodka kościelnego w Dyrrachion posiada pewne specyficzne cechy.

Stosunkowo dobrze zachowane zasoby źródeł sfragistystycznych ułatwiają studia nad prosopografią biskupów i pozostałych duchownych, co otwiera możliwość rekonstrukcji struktur organizacyjnych metropolii, czy biografii niektórych z jej hierarchów we wczesnych wiekach średnich. Trudniej jednak je wykorzystać w badaniach nad lokalną świadomością religijna, oddziaływania na nią sporów teologicznych, czy dyscyplinarnych tamtego okresu' ${ }^{6}$.

Pamiętać należy również, że większość zachowanych źródeł pisanych dotyczących dyrracheńskich struktur kościelnych powstała w określonej relacji z projektami niektórych cesarzy i patriarchów realizowanymi w tej części państwa bizantyńskiego. $Z$ tej perspektywy stosunkowo dogodnie można śledzić historię miejscowego ośrodka, tym bardziej, że w oparciu o zachowane materiały źródłowe zarysowują się następujące jej płaszczyzny: dostępne wykazy jednostek kościelnych podległych patriarsze (Notitiae episcopatuum Ecclesiae Constantinopolitanae) $)^{7}$ oraz personalne potwierdzenia udziału biskupów dyrracheńskich na synodach w VII i VIII wieku.

Spośród 21 zachowanych redakcji wykazów biskupstw patriarchatu, datowanych na VII-XV w., Dyrrachion pojawia się z pewną dozą regularności w 14 przypadkach ${ }^{8}$. Wśród nich dadzą się dostrzec dwie tendencje. W świetle pierwszej grupy wykazów: Notitia 7 (pocz. X w.) $)^{9}$, Notitia 9 (X w. $)^{10}$, Notitia

${ }^{5}$ Por. L. Duchesne, L'Illyricum ecclésiastique, ByzZ 1 (1892) 531-550; Tabula Imperii Byzantini, t. 3: Nikopolis und Kephallennia, hrsg. von P. Soustal, unter Mitwirkung von J. Koder, Wien 1981, 83; D.J. Pallas, Epirus, w: Encyclopedia of the Early Church, t. 1: A-M, ed. by A. Di Berardino, transl. by A. Walford, Cambridge 1992 (sub verbo); L. Miraj, The Chapel in the Amphitheater of Dyrrachium and its Mosaics, w: Progetto Durrës. L'indagine sui beni culturali albanesi dell' Antichità e del Medioevo: tradizioni di studio a confronto, a cura di M. Buoro - S. Santoro, Trieste 2003, 245-290, spec. 247.

${ }^{6}$ Por. J. Dudek, Metropolici Dyrrachion od VII do XIII wieku. Próba charakterystyki, w: Balcanica Posnaniensa. Acta et studia, t. 18, red. I. Czamańska - W. Szulc, Poznań 2011, 67-82.

${ }^{7}$ Por. Notitiae episcopatuum Ecclesiae Constantinopolitanae (= NEEC). Texte critique, introduction et notes par J. Darrouzès, Publications de l'Institut Français d'Études Byzantines. Géographie Ecclésiastique de l'Empire Byzantin 1, Paris 1981. Fragmenty tego źródła zostały przełożone na język polski, zob. Testimonia najdawniejszych dziejów Słowian (seria grecka), z. 4: Pisarze z VIII-XII wieku, red. A. Brzóstkowska - W. Swoboda, Prace Slawistyczne 106, Warszawa 1997, s. 25-79 (notitiae: 2-14).

${ }^{8}$ Por. NEEC, Notitiae: 3 i 7-19.

${ }^{9}$ Por. NEEC, 7, nr 42 (643-647); zob. Testimonia, z. 4, s. 42.

${ }^{10}$ Por. NEEC, 9, nr 42 (517-521); zob. Testimonia, z. 4, s. 52. 
13 (poł. XII w.) $)^{11}$, Notitia 14 (kon. XII w.) ${ }^{12}$, Notitia 15 (kon. XIII w.) ${ }^{13}$, Notitia 16 (XIV w.) $)^{14}$, Notitia 17 (pocz. XIV w.) ${ }^{15}$, Notitia 18 (pocz. XIV w.) ${ }^{16}$ i Notitia 19 (poł. XIV w.) ${ }^{17}$, informacje o Dyrrachion ograniczają się do wyłącznego wzmiankowania nazwy tego ośrodka (Notitiae 14, 15, 16, 17, 18, 19). Tylko nieliczne wykazy z tej grupy (Notitiae $7,9,13)$ zawierają również listę eparchii podporządkowanych biskupowi z Dyrrachion. Listy te są krótkie, jednak wiele przemawia za tym, że odzwierciedlają realny zakres zwierzchnich uprawnień lokalnych hierarchów ${ }^{18}$. Terytorium, na którym znajdowały się wymienione w nich miasta (Dyrrachion, Stefaniakon, Chunavia, Kroja i Elisssos), mogło pokrywać się z hipotetycznymi rozmiarami temu dyrracheńskiego w IX-X wieku $^{19}$.

W wypadku drugiej tendencji wyraźne jest natomiast odwołanie do danych z epoki antyku, co dostrzegalne jest w spisie biskupstw (Notitia 3), pochodzącym przypuszczalnie z 2. poł. VIII wieku. Ów tekst znany czasami jako Notitia Isaurororum czy Noticja Ikonoklastów funkcjonuje w literaturze przedmiotu od ponad stu lat, odkąd został opublikowany za sprawą Karola de Boora (1848-1923) ${ }^{20}$. Od tego czasu kwestia wiarygodności tego przekazu dla poznania polityczno-etnicznego obrazu Bałkanów we wczesnym średniowieczu jest przedmiotem dyskusji. Wynika to z formy tekstu, którego autor (autorzy) w dużej mierze kompilowali starsze zestawienia późnoantycznych miast z V-VI w., zamieszczone w Synekdemosie Hieroklesa (VI wiek). Lista ośrodków kościelnych została jednak uzupełniona o autentyczne, niewątpliwie cenne dodatki, w postaci wykazów nowych biskupstw położonych poza granicami Cesarstwa (np. w Chazarii), lub terytorialnych nabytków Konstantynopola w zachodniej części Półwyspu Bałkańskiego ${ }^{21}$. Obejmują one m.in. Kościół

${ }^{11}$ Por. NEEC, 13, nr 43 (44) (661-666); zob. Testimonia, z. 4, s. 62.

${ }^{12}$ Por. NEEC, 14 (46); zob. Testimonia, z. 4, s. 68.

${ }^{13}$ Por. NEEC, 15 (42).

${ }^{14}$ Por. NEEC, 16 (42).

${ }^{15}$ Por. NEEC, 17 (50).

${ }^{16}$ Por. NEEC, 18 (50).

${ }^{17}$ Por. NEEC, 19 (55).

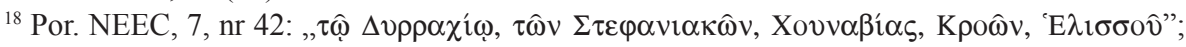
zob. Testimonia, z. 4, s. 42.

19 Por. J. Ферлуга, Драч и њгова област од VII до почуетка XIII века, „Глас. Српска Академија Наука и Уметности. Одељења Историјских Наука” 343/5 (1981) 65-120; J. Dudek, „Cała ziemia dyrracheńska” pod panowaniem bizantyńskim w latach 1005-1205, Zielona Góra 1999, 93-94; G. Prinzing, Elissos (Lezha) oder Kroai (Kruja)? Zu Anna Komnenes problematischer Beschreibung der mittelalbanischen Küstenregion zwischen Elissos und Dyrrachion (Dürres) um 1107, w: Byzantina Mediterranea. Festschrift für Johannes Koder zum 65. Geburstag, hrsg. von K. Belke (et alii), Wien - Köln 2007, 503-515.

${ }^{20}$ C. de Boor, Analekten (I-III). Nachträge zu den Notitiae Episcopatuum, ZKG 12 (1891) 303322 i 519-534; tamże, 14 (1893) 573-599 (= NEEC, s. 20-33 i 229-245).

${ }^{21}$ Por. T.E. G(regory), Hierokles, w: The Oxford Dictionary of Byzantium, II: Esot-Nika, s. 930. 
dyrracheński, nawiązując zresztą do wykazu Hieroklesa. Zakres terytorialny metropolii pokrywa się tutaj z granicami prowincji Nowego Epiru z IV-VI wie$\mathrm{ku}^{22}$. Z tej przyczyny, w przeciwieństwie do partii np. dotyczących Peloponezu lub Beocji, odmawiano temu fragmentowi większej wartości poznawczej23. Rzeczywiście, większość z wymienionych tutaj eparchii, zwłaszcza umiejscowionych poza nadbrzeżnym pasem (Amantia, Atras, Byllis, Campos, Lychnidos) prawdopodobnie zamarła $\mathrm{w}$ niespokojnych czasach, jakie nastały po przybyciu barbarzyńców na zachodnie Bałkany w VI-VII wieku.

2. Status metropolii w VII-X wieku. Operacje militarne i działania dyplomatyczne, podejmowane przez ostatnich cesarzy z dynastii heraklejskiej pod koniec VII w., przywróciły kontrolę nad niektórymi społecznościami Półwyspu Bałkańskiego, zwłaszcza tymi, które po zaburzeniach tamtego stulecia pozostawały w pewnej izolacji od politycznego i kościelnego centrum Cesarstwa. Obce inwazje mogły przetrwać nawet społeczności chrześcijańskie zamieszkujące miasta i osady wewnątrz Półwyspu Bałkańskiego, zmuszone pod naciskiem konieczności uznać jakąś formę zwierzchności barbarzyńskich ludów. W przypadku zachodniej części Półwyspu skala penetracji tych ziem przez najeźdźców mogła być na przełomie VI-VII w. bardzo głęboka, co potwierdza późniejsza pamięć historyczna Bizantyńczyków ${ }^{24}$. Utrwala ona rów-

Por. Ив. Снегаров, Епархийски списъци като исторически извори за християнизацията на балканските славяни, „Известия на Института за Българска История” 6 (1956) 647-654; T. Wasilewski, Bizancjum i Stowianie w IX wieku. Studia z dziejów stosunków politycznych i kulturalnych, Rozprawy Uniwersytetu Warszawskiego 57, Warszawa 1972, 28-35; E. Kountoura, The Presence of the province of Epirus Nova in the socalled „Notitia of the Iconoclast”, w: The Mediaeval Albanians, ed. by Ch. Gasparçs, Athens 1998, 167-176; C. Zuckerman, Byzantium's Pontic Policy in the „Notitiae episcopatuum”, w: La Crimée entre Byzance et le Khaganat Khazar, éd. par C. Zuckerman, Paris 2006, 201-230; M. Salamon, Einige Bemerkungen zur Notitia episcopatuum des Codex Parisinus 1555A, w: Byzantium, New Peoples, New Powers: The Byzantino-Slav Contact Zone, from the Ninth to the Fifteenth Century, ed. by M. Kaimakamova - M. Salamon M. Smorąg Różycka, Byzantina et Slavica Cracoviensia 5, Cracov 2007, 89-102.

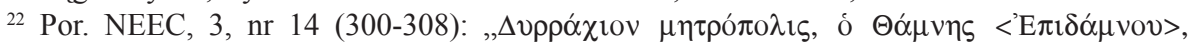

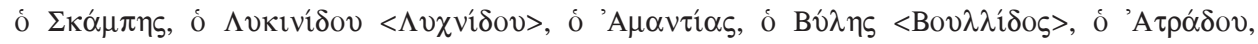

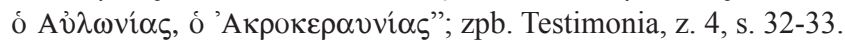

${ }^{23}$ Por. Wasilewski, Bizancjum i Stowianie w IX wieku, s. 33.

${ }^{24}$ Por. Constantinus Porphyrogenitus, De administrando imperio 29, 31, 33 i 35, ed. by G. Moravcsik - R.J.H. Jenkins, Washington 1967, 122-125, 148-149, 154-155 i 164-165; zob. też Konstantyn Porfirogeneta, O rzqdzeniu państwem, w: Testimonia najdawniejszych dziejów Słowian (seria grecka), z. 2: Pisarze z V-X wieku, red. A. Brzóstkowska - W. Swoboda, Prace Slawistyczne 63, Wrocław - Warszawa 1989, 297-325 (cap. 2, 4, 9, 13 i 28-30, spec. s. 309 [cap. 29]); Konstantyn Porfirogeneta, O rzqdzeniu państwem, w: Testimonia najdawniejszych dziejów Słowian (seria grecka), z. 3: Pisarze z VII-X wieku, red. A. Brzóstkowska - W. Swoboda, Prace Slawistyczne 103, Warszawa 1995, 431-461 (cap. 31-37 i 49-50), spec. s. 431, 446 i 448 (cap. 31, 33 i 35); por. też W. Pohl, Die Awaren. Ein Steppenvolk in Mitteleuropa, 567-822, München 1988 (Frühe Völker), 64-89, 99-112, 121-162 i 237-255. 
nież informację o pierwszych inicjatywach osadniczych władz bizantyńskich na opustoszałych terenach tej części Bałkanów. Jeśli wierzyć Konstantynowi VII Porfirogenecie (913-959) pierwsza faza tego procesu miała się rozpoczać jeszcze w VII w., kiedy to cesarz Herakliusz (610-642) zezwolił, by plemiona Chorwatów i Serbów przejęły na swoje siedziby niektóre regiony dawnej prowincji Dalmacji ${ }^{25}$. Podobne przemieszczenia lojalnych wobec Cesarstwa grup barbarzyńców czy pół-barbarzyńców wystąpiły również pod koniec stulecia, kiedy grupa Bułgara Kubera (VI w.) po opuszczeniu Panonii miała się osiedlić

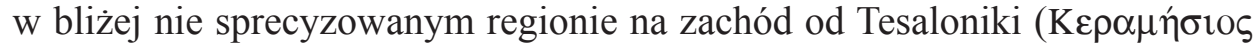
$\kappa \alpha ́ \mu \pi \mathrm{s})^{26}$. Wiedza Bizantyńczyków o podobnych migracjach odnosiła się również do tych mieszkańców Cesarstwa, którzy szukali dla siebie nowych bezpiecznych siedzib, przemieszczając się od zagrożonego pogranicza dunajskiego na południe, ku górzystym regionom na pograniczu Epiru i Tesalii, tak jak to miało miejsce w przypadku Wołochów, opisanym przez jednego $z$ jedenastowiecznych autorów ${ }^{27}$. Oczywiście, oprócz powyższych imigrantów należy również uwzględnić rolę grup autochtonów, które przetrwały na obszarach dawnych prowincji epirockich obce inwazje w bardziej czy mniej sprzyjających warunkach geograficznych, zachowując częściowo swoją tożsamość religijną. Pewnym potwierdzeniem występowania takich enklaw, mogących również wchodzić w bliższe lub dalsze zależności z imigrantami z północnej części Półwyspu, mogli być twórcy kultury Komani-Kroja, której rozproszonych stanowisk można się doszukać na obszarach Nowego i Starego Epiru, zarówno na lądzie stałym (od południowej Dalmacji po Pelagonię), jak i na Wyspach Jońskich ${ }^{28}$.

${ }^{25}$ Por. Constantinus Porphyrogenitus, De administrando imperio 29, 31 i 34, ed. by Moravesik - Jenkins, s. 124-125, 148-149 i 163-164; zob. Konstantyn Porfirogneta, O rzqdzeniu państwem, w: Testimonia, z. 2, s. 309-310 (cap. 29); tamże, z. 3, s. 431-432 (cap. 31) i 448 (cap. 34).

${ }^{26}$ Por. Les plus anciens recueils des miracles de Saint Démétrius et la penetration des Slaves dans les Balkans, publié, traduit et commenté par P. Lemerle, vol. 1: Le texte (Le Monde Byzantin), Paris 1979, 227-230; vol. 2: Commentaire (Le Monde Byzantin), Paris 1981, 137-150; zob. Cuda św. Dymitra, w: Testimonia, z. 2, s. 210-216.

${ }^{27}$ Советы и рассказы Кекавмена: сочинение византийского полководияа ХІ века, подгот. текста, введение, пер. и комментарий Г.Г. Литаврина, Москва 1972, 268 (26-29), 270 (1-5). W kwestii ogólnego obrazu tych migracji, por. H. Ditten, Etnische Verschiebungen zwischen der Balkanhalbinsel und Kleinasien vom Ende des 6. bis zur zweiten Hälfe des 9. Jahrhunderts, Berliner Byzantinistische Arbeiten 59, Berlin 1993; M. Salamon, The Inscription of Dulcissimusa the Bishop of Dorostolon, in Odessos, „Byzantinoslovaca” 2 (2008) 49-59.

${ }^{28}$ Por. В. Поповић, Албанија у касној античи, w: Илири и Албанции, серија предавања одржаних од 21. маја до 4. јуна 1986 године, уредник М. Гарашанин, Научни Скупови 39. Одељење Историјских Наука 10, Београд 1988, 201-252, spec. 231-245; W. Bowden, The Construction of Identities in post-Roman Albania, w: Theory and Practice in Late Antique Archaeology, ed. by L. Lavan - W. Bowden, Late Antique Archaeology 1, Leiden 2003, 57-78; S. Turlej, Trwanie i zmiany. Stosunki etniczne na Bałkanach w okresie VI-X w., w: Wędrówka i etnogeneza w starożytności i średniowieczu, red. M. Salamon - J. Strzelczyk, Kraków 2004, 219-236, 
Sugestia, że w związku z obecnością powyższych grup można mówić o pełnej restauracji eparchii metropolii dyrracheńskiej w zakresie przedstawionym przez Notitia 3 wydaje się jednak zbyt daleko idąca. W świetle dotychczasowych danych na obszarze dawnej prowincji Nowego Epiru prawie całkowicie zamarła aktywność w dziedzinie budownictwa sakralnego. Pewne skromne jej oznaki można zaobserwować tylko w Dyrrachion, gdzie na dawnym hipodromie zbudowano kaplice, datowaną na VII-X wiek ${ }^{29}$. Stanowiska kultury Komani-Kroja, zresztą obejmujące głównie nekropole, potwierdzają tylko przetrwanie pewnych społeczności nawiązujących do dawnych tradycji, w sporym stopniu jednak zbarbaryzowanych i wymieszanych z imigrantami. Chociaż lokalizacja niektórych stanowisk pokrywa się z zachodnim odcinkiem Via Egnatia, to jednak ów szlak komunikacyjny uległ w zasadzie przerwaniu pod koniec VI w. i nic nie zdaje się wskazywać, by mógł być on wykorzystany przez najbliższe dwa stulecia w celach wojskowych, dyplomatycznych czy handlowych ${ }^{30}$. Stąd ,wywołanie” figurujących w tym spisie antycznych biskupstw przez redaktorów spisu, wydaje się być powiązane nie tyle z realnymi owocami bizantyńskiej „rekonkwisty”, lecz raczej stanowić formę zamanifestowania formalnego zasięgu zwierzchności patriarchatu Nowego Rzymu w tej części zachodnich Bałkanów pod koniec VIII wieku.

O tym jak dogodne mogło być to narzędzie dla patriarchatu poświadczać może kolejny źródłowy dowód w postaci jednego z późniejszych wykazów biskupstw (Notitia 10), zredagowanego prawdopodobnie bezpośrednio po latach 969-972. W obrębie metropolii dyrracheńskiej miały się znaleźć nie tylko wymieniane w poprzednich spisach „stare” sufraganie: Chounabia, Elissos, Kroja i Stefaniakion. Dodatkowo na liście znalazły się takie nowe

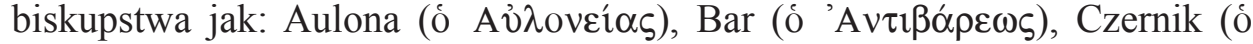

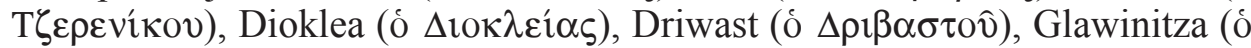
$\left.\Gamma \lambda \alpha \beta \imath v^{\prime} \tau \zeta n \varsigma\right)$, Graditzina (ó $\left.\Gamma \rho \alpha \delta i \tau \zeta \imath v\right)$, Ochryda (ó $\left.\Lambda v \kappa \imath v i ́ \delta \omega v\right)$, Polat (ó

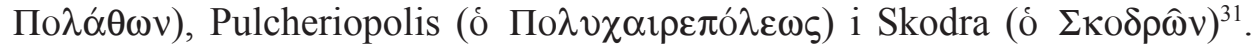
Zakres władzy metropolitów miał obejmować rozległe terytorium, pokrywające się w przybliżeniu z granicami dwóch starożytnych prowincji: Nowego

spec. przyp. 57. Mimo pewnych wspólnych elementów zachowane stanowiska archeologiczne cechuje szereg różnic. Trudno więc jednoznacznie przypisać twórców tej kultury od określonej grupy etnicznej, np. do Albańczyków.

${ }^{29}$ Por. Miraj, The Chapel in the Amphitheater of Dyrrachium and its Mosaics, s. 247.

${ }^{30} \mathrm{Jak}$ udowadnia M. McCormick (Narodziny Europy. Korzenie gospodarki europejskiej. 300900, thum. A. Bugaj - Z. Dalewski - J. Lang - I. Skrzypczak, Warszawa 2007, 480-487 i 534-538), przynajmniej do IX w. Konstantynopol komunikował się ze światem zachodniego chrześcijaństwa drogą morską, za pośrednictwem portów greckich na Peloponezie.

${ }^{31}$ Por. G. Parthey, Hieroclis Synecdemus et notitiae graecae episcopatuum, accedit Nili Doxapatrii notitia patriarchatuum et locorum nomina immutata, Lipsiae 1866, 202-224; NEEC 10, $\mathrm{nr} 43$ (42) (607-623); zob. Notitiae episcopatuum ecclesiae Constantinopolitanae, w: Testimonia, z. 4 , s. $55(42,1-15)$ i s. 75 , przyp. 106 (komentarz). 
Epiru i Prewalitany. Przekaz, w opinii wydawcy, odzwierciedla zmiany polityczne zaszłe po podboju Bułgarii przez cesarza Jana Tzymiskesa (969-976) ${ }^{32}$. Nie wydaje się jednak być to interpretacja wyczerpująca. Ramy geograficzne metropolii zamieszczone $\mathrm{w}$ przekazie pochodzącym $\mathrm{z}$ tej listy wydają się być podobne do charakterystyki Dyrrachion i związanych z tym ośrodkiem miast i ziem, zamieszczonej w pracy $O$ temach, powstałej przypuszczalnie w latach 933-944 ${ }^{33}$. Tekst oparty został zapewne, podobnie jak w wypadku niektórych partii Notitia 3, na starszych danych pochodzących z VI wieku. W przekazie Porfirogenety dyrracheński ośrodek polityczny dominuje nie tylko nad antycznym Nowym Epirem. Przyporządkowane zostały mu również dawne prowincje z IV-V w. (Dardania, Dacja i Panonia), którymi cesarscy strategowie z Dyrrachion nigdy żadną miarą nie mogli bezpośrednio zarządzać po utworzeniu tamtejszego temu na początku IX wieku ${ }^{34}$. Wiadomo, że zamieszkujące ten region różne ludy (Serbowie, Chorwaci) były przedmiotem zabiegów cesarskiej dyplomacji. Brak jednak podstaw, by domniemywać, żeby samo Dyrrachion było punktem wyjściowym dla podobnych przedsięwzięć adresowanych do ludów nad środkowym Dunajem (Węgrzy) ${ }^{35}$.

Wydaje się, że w przypadku dwóch powyższych wykazów biskupstw i temów mamy do czynienia nie tyle z opisem faktycznie działających instytucji kościelnych czy bizantyńskich jednostek administracyjnych, co z pewną wizją porządku politycznego i kościelnego w tej części Półwyspu Bałkańskiego, formułowaną $\mathrm{z}$ perspektywy stołecznych władz. W takim wypadku zapis Porfirogenety należy odnieść do ewentualnego ówczesnego (1. poł. X w.) zakresu bizantyńskiego programu ,rekonkwisty” wobec zachodniej części Półwyspu Bałkańskiego, przewidzianego do realizacji w bliżej nie sprecyzowanej przyszłości.

Takie postrzeganie Dyrrachion jako newralgicznej placówki w warunkach IX-X w. mogło być również reakcją Konstantynopola na dynamiczną ekspansję państwa Bułgarów w tej części Bałkanów. Już tacy pogańscy chanowie, jak Małamir (831-836), czy Presjan (836-852) narzucili swoją władzę więk-

32 Por. NEEC, s. 115-116.

33 Por. Constantinus Porfyrogenitus, De thematibus, a cura di A. Pertusi, Vatican 1952,

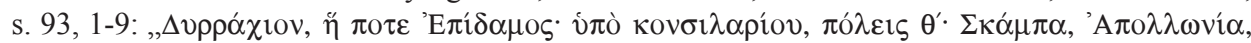

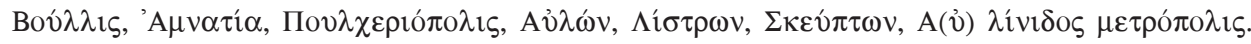

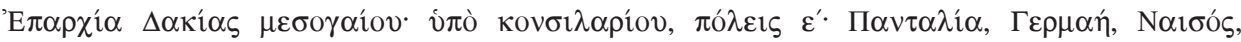

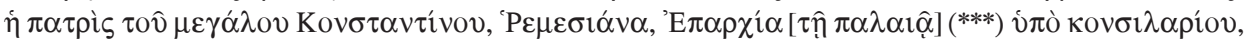

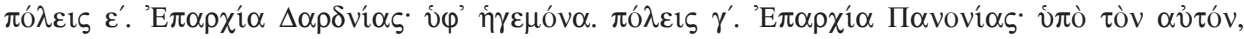
$\pi$ ó $\lambda \varepsilon 1 \varsigma$ $\beta^{\prime \prime \prime}$; zob. A.P. K(azhdan), De Thematibus, w: The Oxford Dictionary of Byzantium, I, s. 614-615.

${ }^{34}$ Por. Constantinus Porfyrogenitus, De thematibus, a cura di A. Pertusi, Vatican 1952, s. 93 , 4-8.

${ }^{35}$ Por. T. Živković, Sources de Constantin VII Porphyrogénète concernant le passé le plus ancient des Serbes et des Croates, „Byzantina Symmeikta” 20 (2010) 11-37. 
szości autonomicznych społeczności osiedlonym wzdłuż zachodniego odcinka dawnej Via Egnatia. Konwersja Borysa-Michała (852-889) i zainicjowanie procesu chrystianizacji Bułgarów nie wyeliminowała tego zagrożenia dla interesów bizantyńskich w tej części Bałkanów. Kolejni, poczynając od tego pierwszego chrześcijańskiego chana, władcy Bułgarii w X w. dążyli to ustanowienia odrębnej od patriarchatu konstantynopolitańskiego organizacji kościelnej. Wiadomo, że przywiązywali oni duże znaczenie do budowy jej zrębów również w prowincjonalnych ośrodkach swojego państwa, a szczególnie na jego zachodnich peryferiach, graniczących z posiadłościami bizantyńskimi w Dyrrachion. W przypadku obszaru bułgarskiego komitatu Kutmiczewicy pewną rolę w tych staraniach odegrał św. Klemens (ok. 840-916) i jego uczniowie, którzy z woli Borysa-Michała zostali skierowani na te tereny po $885 \mathrm{roku}^{36}$. O randze tych procesów dla późniejszej historii kościelnej tej części Bałkanów może świadczyć m.in. tamtejsza lokalizacja polityczno-religijnego centrum odrodzonej Bułgarii (tzw. państwo Komitopulów) pod koniec $\mathrm{X}$ wieku.

Ambicje polityczne Samuela (997-1014) i jego następców, konsekwentnie wspierających podległą sobie hierarchię kościelną zapewne przyczyniły się do podsycenia zagrożenia dla stanu posiadania patriarchatu konstantynopolitańskiego, tym bardziej, że pod kontrolą Bułgarów znalazło się wówczas samo Dyrrachion (do roku 1005). Lista biskupstw ówczesnego Kościoła bułgarskiego datowana na rok 1000, wymieniona w inskrypcji z kościoła św. Achillesa w Prespie, obejmowała zapewne również dawne ośrodki podlegające patriarchatowi Konstantynopola ${ }^{37}$.

${ }^{36}$ Por. П. Коледаров, О местонахождений средневекового города Девол и пределах одноименной области (I и II част), „Paleobulgarica” 6 (1982) nr 1, 87-101; 6 (1982) nr 2, 75-90; Б. Панов, Охрид и охридската област во време на буларското владеење (средината на IX в. - 969 година), w: tenże, Средновековна Македонија, t. 3, Скопље 1985, 680-715; W. Swoboda, Devol, w: Słownik Starożytności Stowiańskich, t. 8, cz. 1, s. 36-39. W kwestii aktywności św. Klemensa na ziemiach Kutmiczewicy, por. Teofilakt arcybiskup Ochrydy, Żywot $i$ dokonania, $i$ wyznanie i opisanie niektórych cudów jednego z naszych świętych ojców, Klemensa, (Legenda bułgarska), w: Uczniowie Apostołów Słowian. Siedmiu Świętych Mężów, oprac. M. Skowronek G. Minczew, Biblioteka Duchowości Europejskiej 4, Kraków 2010, 109-110; Kliment of Ochrid, w: The Oxford Dictionary of Byzantium, II, s. 1133-1134; W. Swoboda - L. Moszyński, Kliment, w: Stownik Starożytności Stowiańskich, t. 2: F-K, Wrocław - Warszawa 1964, 423-425; W. Swoboda, Naum, w: Stownik Starożytności Stowiańskich, t. 3: L-O, Wrocław - Warszawa 1968, 356-357; J. Dudek, Kościót prawosławny na ziemiach albańskich do podboju osmańskiego (w druku).

${ }^{37}$ Por. Й. Иванов, Български старини из Македония, София 1970 [reprint wydania z r. 1931], 55-57. Napis jest uszkodzony i zachował się tylko częściowo. Јuż И. Снегаров (История на Охридската архиепископия, t. 1: От основаванетой до завладяването на Балканския полуостров от туриите, София 1995 [reprint wydania z r. 1924], 22-25) wyraził przekonanie, że pierwotna lista była znacznie obszerniejsza i obejmowała również takie ośrodki kościelne, jak Larissa czy Dyrrachion, znajdujące się w tamtych latach pod polityczną kontrolą Bułgarów. 
Ostateczny podbój Bułgarii w 1018 r. i utworzenie autokefalicznego arcybiskupstwa w Ochrydzie zamyka określony rozdział w historii kościelnej tej części Półwyspu Bałkańskiego. Chociaż zwycięski cesarz Bazyli II (9761025) poczynił pewne koncesje na rzecz kapitulujących Bułgarów, to jednak zostały zabezpieczone żywotne interesy patriarchatu konstantynopolitańskiego $^{38}$. Metropolia dyrracheńska, chociaż w okrojonych rozmiarach, pozostała podporządkowana bezpośredniej jurysdykcji stołecznych władz kościelnych ${ }^{39}$. Spory terytorialne zostały zredukowane do rywalizacji kościelnych instytucji, pozostających jednak (nawet w przypadku Ochrydy) pod mniejszym lub większym wpływem duchownych powiązanych z Konstantynopolem ${ }^{40}$.

Prawdopodobnie znacznie wcześniej i z korzyścią dla stołecznego patriarchatu, została ustalona kwestia personalnego statusu hierarchów dyrracheńskich w kościelnych zgromadzeniach. Zachowana lista biskupów z Dyrrachion w okresie późnoantycznym nosi wprawdzie wyraźnie szczątkowy charakter, jednak mimo to pozwala ona $\mathrm{w}$ pewnym stopniu prześledzić proces zacieśniania się ich związków z patriarchatem Konstantynopola ${ }^{41}$. Dotyczy to zwłaszcza dwóch znanych zgromadzeń wyższego duchowieństwa, po których zachowały się listy ich uczestników.

Jeszcze do początku VIII stulecia, jako biskupi przynależni do regionu Illyricum, hierarchowie z Dyrrachion formalnie podlegli Stolicy Apostolskiej czuli się zobligowani do uczestnictwa w lokalnych synodach (np. w 515 r.), podtrzymujących więź ze Stolicą Apostolską. Jednak przed rozporządzeniem cesarza Leona III można dostrzec sygnał zmian w przyporządkowaniu miejscowych Kościołów.

${ }^{38}$ Por. Иванов, Български старини из Македония, s. 547-562; Regesten der Kaiserurkunden des östromischen Reiches von 565-1453, bearbeite von F. Dölger, 1. Teil, 2. Halband: Regesten von 867-1025, Corpus der Griechischen Urkungen des Mittelalters und der Neuen Zeite, Reihe A: Regesten, Abteilung 1: Regesten der Kaiserurkunden des Oströmischen Reiches, München $2003^{2}$ (neu bearbeitet von A.E. Müller), nr 806. 807. 808.

${ }^{39}$ Zaznacza się więc stabilizacja zasięgu terytorialnego Kościoła dyrracheńskiego, utrzymana aż do ostatecznego zmierzchu władzy bizantyńskiej w tym regionie na początku XIV wieku. Dopiero ostatnie średniowieczne Notitiae episcopatuum ograniczały się już tylko do zarejestrowania obecności Dyrrachion w gronie ośrodków podległych patriarchatowi Konstantynopola, bez uwzględnienia należących do tej metropolii eparchii, por. NEEC, 15 (42). 16 (14). 17 (50). 18 (50). 19 (55).

${ }^{40}$ Poczynając od połowy XI w. kolejni arcybiskupi byli z pochodzenia przeważnie Grekami, a a zatem duchownymi przeważnie ściśle związanymi z Wielkim Kościołem, por. Снегаров, История на Охридската архиепископия, t. 1, s. 195-213. Uwypuklanie rangi autokefalii arcybiskupstwa bułgarskiego poprzez konsekwentne nawiązanie do kontynuacji tradycji Iustiniana Prima również pozostawało zgodne z interesem państwa i Kościoła bizantyńskiego, por. G. Prinzing, Entstehung und Rezeption der Iustiniana-Prima-Theorie im Mittelater, „Byzantinobulgarica” 5 (1978) 269-287.

${ }^{41}$ Por. R. Janin, Dyrrachium, DHGE XIV 1248-1252; Hierarchia ecclesiastica Orientalis: series episcoporum ecclesiarum christianarum orientalium, I: Patriarchatus Constatinopolitanus, a cura di G. Fedalto, Padova 1988, 528-530. 
Dowody tego stanu rzeczy można zaobserwować na przykładzie listy uczestników Synodu Trullańskiego (Quinisextum) z 692 roku $^{42}$. Zachowana partia jego materiałów była sygnowana przez ponad 200 uczestników, włącznie z samym inicjatorem tego przedsięwzięcia - cesarzem Justynianem II (685$695,705-711)^{43}$. W ich gronie wyraźnie dominowali biskupi lub ich przedstawiciele $\mathrm{z}$ dotychczasowego obszaru patriarchatu konstantynopolitańskiego. Jednak jedno z najwyższych, honorowych miejsc na liście, bezpośrednio po cesarzu, zarezerwowano dla papieża Sergiusza I (687-701), ewentualnie dla jego przedstawiciela, który miał zatwierdzić uchwały synodu ${ }^{44}$. Pojawili się również i zostali wyróżnieni, zgodnie z ideą pentarchii, wschodni patriarchowie: Piotr VI (ok. 690-695) z Aleksandriiis ${ }^{45}$ Jerzy II (690-695) z Antiochiii ${ }^{46}$ i Anastazjusz II (ok. 692-706) z Jerozolimy ${ }^{47}$, aczkolwiek ich siedziby były już od pół wieku pod panowaniem muzułmańskim.

Godnym podkreślenia jest to, że na liście uczestników synodu wyeksponowana została ranga biskupów z zachodniej części Bałkanów (Dyrrachion, Gortyna, Korynt, Tesalonika), formalnie podlegającym papieżowi. Znaleźli się tam oni w grupie dygnitarzy umieszczonych bezpośrednio po cesarzu, po miejscu zarezerwowanym dla papieża i po podpisach patriarchów Wschodu ${ }^{48}$. $\mathrm{Z}$ innych kościelnych dygnitarzy, w prawie tej samej partii tekstu subskrybowano tylko następujących biskupów: Ankary, Cezarei Kapadockiej, Efezu, Heraklei Trackiej, Rawenny i Sardynii ${ }^{49}$. Taka precedencja biskupów zachodnich zapewne nie była dziełem przypadku, lecz wynikała z obranego przez Justyniana II kierunku postępowania, którym było dążenie do konsolidacji Cesarstwa i Kościoła wobec nadchodzącej konfrontacji ze światem islamu ${ }^{50}$.

Wysoka, 17. pozycja na liście, osiąnnięta przez biskupa Sisinniosa z Dyrrachion, niezależnie od potwierdzenia jego metropolitalnego statusu, to rezultat splotu pewnych okoliczności ${ }^{51}$. Na synodzie nie stawili się osobiście

42 Por. H. Ohme, Das Concillium Quinisextum und seine Bischofsliste. Studien zum Konstantinopeler Konzil von 692, Arbeiten zur Kirchengeschichte 56, Berlin - New York 1990, 145-175 (Der Text der Subskriptionsliste); zob. R. Flogaus, Das Concilium Quinisextum (691/692) Neue Erkenntnisse über ein umstrittenes Konzil und seine Teilnehmer, ByzZ 102 (2009) nr 1, 25-64, spec. 60-61.

${ }^{43}$ Por. Ohme, Das Concillium Quinisextum, s. 145 (1).

${ }^{44}$ Por. tamże, s. 145 (2).

${ }^{45}$ Por. tamże, s. 145 (4).

${ }^{46}$ Por. tamże, s. 145 (5).

${ }^{47}$ Por. tamże, s. 145 (6); zob. tamże, s. 207.

${ }^{48}$ Por. tamże, s. 145 (8) i s. 146 (14. 15. 17); zob. tamże, s. 210 i 227.

${ }^{49}$ Por. tamże, s. 146 (9 [Cezarea Kapadocka], 10 [Sardynia], 11 [Efez].,12 [Rawenna], 13 [Heraklea Tracka] i 16 [Ankara]); zob. tamże, s. 197.

${ }_{50}$ Por. J.F. Haldon, Byzantium in the Seventh Century. The transformation of a culture, Cambridge 1990, $73-74$ i 313-323.

${ }^{51}$ Por. Ohme, Das Concillium Quinisextum, s. 146 (17): „,

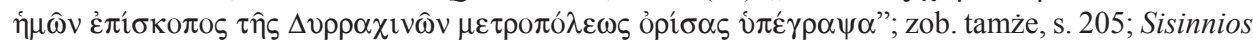


metropolici dwóch prestiżowych i mocno zakorzenionych w tradycji chrześcijańskiej ośrodków: Tesaloniki i Koryntu. W konsekwencji organizatorzy synodu zostali niejako zmuszeni do pozostawienia na przedmiotowej liście wolnych miejsc, przeznaczonych na ich podpisy. Zdaniem Gilberta Dagrona mogło to wynikać z zagrożenia ich siedzib przez barbarzyńców lub z poparcia papieża Sergiusza i jego następców, jak wiadomo, niechętnie ustosunkowanych do uchwał synodu z 692 roku $^{52}$. Warto jednak zwrócić uwagę, że w przypadku powyższych dwóch metropolii przybyli na synod ich biskupi-sufragani, najliczniej reprezentowani przez delegację tesalonicką (Andrzej z Filippi, Andrzej z Amfipolis, Izydor z Edessy) ${ }^{53}$, znacznie szczuplej w przypadku korynckiej (Sylwan z Lemnos) ${ }^{54}$. Kolejne miejsce na liście, zajął metropolita Bazyli z Gortyny, któremu na synodzie towarzyszyli kreteńscy biskupi-sufragani (Nicetas z Kydony, Theopemtos z Kisamos i Sisinnios z Chersonesos) ${ }^{55}$.

Fakt, że Sisinnios z Dyrrachion na obradach synodu pojawił się samotnie, bez towarzyszących mu biskupów pozostałych miast dawnej prowincji Nowego Epiru, zapewne już nieistniejących czy mocno podupadłych, nie wydaje się mieć w tych okolicznościach istotnego znaczenia. Sisinnios, podobnie jak hierarcha Krety, zaliczony został do grona tych wyróżnionych hierarchów Zachodu, którzy ostatecznie znaleźli się pod obediencją patriarchy Konstantynopola w najbliższych nadchodzących dekadach VIII wieku ${ }^{56}$.

O tym, że powyższa kolejność składania podpisów uczestników synodu nie pozostawała okazjonalnym dziełem przypadku może zaświadczać struktura podobnych zachowanych dokumentów, które złożyły się na sześć, sporządzonych w języku greckim i łacińskim, list hierarchów biorących udział w Soborze Nicejskim II (787) ${ }^{57}$. Obrady rozpoczęły się kilkadziesiąt lat po edykcie Leona III, podporządkowującym biskupstwa zachodniego Illyricum stołecznemu patriarchatowi. Chociaż zasadniczym celem tego zgromadzenia było potępienie ikonoklazmu i przywrócenie jedności kościelnej z papiestwem i pozostałą częścią świata ortodoksyjnych chrześcijan, skutki rozporządzenia cesarskiego w zakresie geografii kościelnej nie zostały uchylone, mimo energicznych zabiegów Stolicy Apostolskiej, kontynuowanych zresztą również w późniejszych stuleciach ${ }^{58}$. Co więcej, zachowane listy ponad 300 uczestni-

8, w: Prosopography of the Byzantine Empire I (641-867), ed. by J. R. Martindale, [CD ROM], Aldershot 2001.

${ }_{52}$ Por. Dagron, Chrześcijaństwo bizantyńskie, s. 34.

${ }^{53}$ Por. Ohme, Das Concillium Quinisextum, s. 152 (61. 63. 64); zob. tamże, s. 205.

${ }^{54}$ Por. tamże, s. 152 (62); zob. tamże, s. 205.

${ }^{55}$ Por. tamże, s. 154 (85); s. 155 (86. 87); zob. tamże, s. 206. W kwestii bliskich relacji metropolii gortyńskiej z papiestwem w VII w., zob. tamże, s. 235-251 (komentarz).

${ }^{56}$ Por. tamże, s. 222-225.

${ }^{57}$ Por. J. Darrouzès, Listes épiscopales du concile de Nicée (787), REB 33 (1975) 5-76; E. Lamberz, Die Bischofslisten des VII. Ökumenischen Konzils (Nicaenum II), München 2004.

${ }^{58}$ Por. Dagron, Chrześcijaństwo bizantyńskie, s. 108-118. 
ków soboru, uwzględniając rozszerzenia, ubytki i zmiany statusu niektórych metropolii, zasadniczo odtwarzają kolejność listy synodu z 692 roku. W wykazie metropolitów, którzy przybyli do Nicei w 787 r., zostali wymieni w następującym porządku biskupi ${ }^{59}$ : Agapios z Cezarei Kapadockiej, Jan z Efezu, (?) z Dalmacji, Konstantyn z Cypru, Teofil z Tesaloniki, Leon z Heraklei Trackiej, Bazyli z Ankary (Galatia I), Mikołaj z Kyzikos, Eutymiusz z Sardes, Piotr z Nikomedii, Hypatios z Nicei, Staurakios z Chalcedonu, (?) z Hellady, Eliasz z Krety, Tomasz z Sardanii (Epifaniusz z Katanii), Leon z Side i Nicefor z Dyrrachion ${ }^{60}$. Większości z nich (Agapiosowi, Janowi, Leonowi, Konstantynowi, Bazylemu, Mikołajowi, Piotrowi, Eliaszowi i Hypatiosowi) towarzyszyli biskupi-sufragani ${ }^{61}$. Metropolita Nicefor z Dyrrachion dotarł do Nicei, podobnie jak jego poprzednik Sisinnios do Konstantynopola w ubiegłym stuleciu, bez żadnego towarzyszącego mu biskupa, został jednak wymieniony w pierwszej grupie metropolitów uczestniczących $\mathrm{w}$ soborze ${ }^{62}$. Jeśli udział Sisinniosa został tylko odnotowany w gronie uczestników synodu, to obecność metropolity Nicefora na powszechnym zgromadzeniu biskupów została skrupulatniej zarejestrowana. $Z$ niewyjaśnionych powodów Nicefor nie został odnotowany na pierwszej liście obecności soborowych obrad ${ }^{63}$. Natomiast pozostałe listy (obecności, głosujących i podpisów) potwierdzają jego obecność na kolejnych sesjach soboru odbywających się między 26 września a 23 listopada 787 roku. Biorąc pod uwagę, że były to posiedzenia, na których przywrócono kult ikon i zerwano z ikonoklazmem, początkowa absencja metropolity nie wydaje się być dyplomatycznym wybiegiem, lecz zapewne została spowodowana innymi, nieznanymi nam czynnikami.

Późniejsze lata niestety nie umożliwiają podobnego wglądu na status metropolitów dyrracheńskich $\mathrm{w}$ geografii kościelnej stołecznego patriarchatu. Brak danych, czy uczestniczyli w podobny sposób w Zwycięstwie Ortodoksji w 843 r., czy też w synodach związanych z tzw. schizmą focjańską. To, że Regesty patriarchatu sporadycznie tylko wzmiankują tę metropolię i jej hierar-

${ }^{59}$ Drukiem wytłuszczonym zostały oznaczone metropolie, których hierarchowie złożyli swoje podpisy w zbliżonej kolejności w 692 roku.

${ }^{60}$ Por. Lamberz, Die Bischofslisten des VII, s. 18 (1-7) I s. 19 (8-10). Por. tamże, s. 42-43.

${ }^{61}$ Por. tamże, s. 51-63.

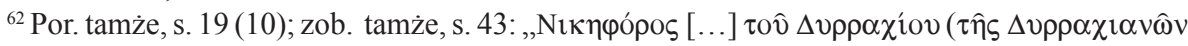

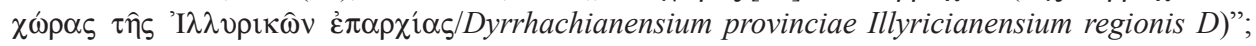
por. Nikephoros 10, w: Prosopography of the Byzantine Empire I (641-867) [CD ROM].

${ }^{63} \mathrm{~W}$ jego imieniu uczestniczył również przybyły z Dyrrachion mnich Jan, por. Lamberz, Die

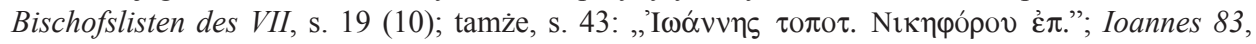
w: Prosopography of the Byzantine Empire I (641-867) [CD ROM]. Niewykluczone, że mógł to być wymieniony na drugiej liście obecności Jan z Kotoru (Lamberz, Die Bischofslisten des VII, s. 78:

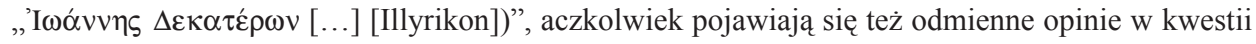
jego macierzystego ośrodka (Tracja?), por. tamże, s. 78, przyp. 383; Ioannes 119, w: Prosopography of the Byzantine Empire I (641-867) [CD ROM]. 
chów w IX-X w., nie musi świadczyć o obniżeniu rangi biskupstwa dyrracheńskiego w bizantyńskich strukturach kościelnych ${ }^{64}$. Taka sytuacji wydaje się być raczej rezultatem stanu zachowania ówczesnego materiału źródłowego, tym bardziej, że w XI stuleciu widoczny staje się raptowny wzrost danych poświęconych metropolii dyrracheńskiej w dokumentach patriarchatu. Zdają się one potwierdzać nie tylko fakt obecności biskupów dyrracheńskich w stolicy, ale również ich wręcz permanentną obecność na niektórych ważnych synodach patriarszych ${ }^{65}$.

$* * *$

Uwzględniając wyżej przedstawione dane można pokusić się o stwierdzenie, że już poczynając od końca VII w. dostrzegalna stała się rola patriarchatu konstantynopolitańskiego na zachodnich Bałkanach. Tamtejsza substancja kościelna, która ocalała po najazdach barbarzyńców, definiowana w literaturze przedmiotu jako „pomost między Wschodem i Zachodem” stała się przedmiotem rywalizacji konkurujących z sobą patriarchatów. W tym procesie przewagę zyskiwał stopniowo patriarchat Konstantynopola, wspierany na różnych polach przez działania cesarzy „Nowego Rzymu”. Stąd trudno jednoznacznie rozdzielić w postępowaniu strony bizantyńskiej inicjatywy cesarskie od kroków podejmowanych przez konkretnych patriarchów i ich pomocników. $\mathrm{Z}$ kilku względów biskupstwo Dyrrachionu odegrało w tej rywalizacji istotną rolę. $Z$ tego punktu widzenia ważne było już samo istnienie miasta jako siedziby biskupa i cesarskich urzędników (archont, strateg). Równie istotne jawi się utrzymanie dawnych walorów ekonomicznych i komunikacyjnych Dyrrachionu z racji położenia jego portu u wylotu Morza Adriatyckiego, po wschodniej stronie Cieśniny Otranto. Te atuty sprawiały, że patriarchowie Konstantynopola mając poparcie swoich cesarzy mogli wykorzystać metropolię dyrracheńską do przejęcia części zadań dotychczasowych ośrodków kościelnych, które uległy prawie całkowitej likwidacji, zarówno tych w głębi lądu (Iustiniana Prima), jak i tych położonych na wybrzeżu dawnego Starego Epiru (Nikopolis) ${ }^{66}$. W efekcie metropolia dyrracheńska stała się od VIIVIII w. znaczącym przyczółkiem wpływów stołecznego patriarchatu w tej czę-

${ }^{64}$ Dzieje się tak np. w kontekście tetragamii cesarza Leona VI (886-912), por.V. Grumel, Les regestes des actes du patriarcat de Constantinople, vol I: Les actes des patriarches, fasc. 2: Les regestes de 715 à 1043, Le Patriarcat Byzantin I 1/2, Constantinople 1936, nr 639.

${ }^{65}$ Tamże, vol. I, fasc. 3: Les regestes de 1043 à 1206, Le Patriarcat Byzantin I 1/3, Constantinople 1947, nr 869,.1015, 1038, 1077 i 1193.

${ }^{66}$ Por. A.P. K(azhdan) - I. Dj(urić) - A. C(utler), Justiniana Prima, w: The Oxford Dictionary of Byzantium, II, s. 1085; Tabula Imperii Byzantini, t. 3: Nikopolis und Kephallēnia, s. 81-83 i 213214; T.E. G(regory), Nikopolis in Epiros, w: The Oxford Dictionary of Byzantium, III: Nike-Zygo, s. 1484; S. Turlej, Justyniana Prima. Niedoceniony aspekt polityki kościelnej Justyniana, Kraków 2011, 211-220. 
ści Bałkanów. Powstanie i rozwój Kościoła bułgarskiego zredukowało w pewnym stopniu zakres terytorialnych zapędów metropolitów. Trzeba jednak mieć na uwadze, że w kręgach prawosławnego duchowieństwa Konstantynopola świadomość wysokiej pozycji osiagniętej przez metropolię dawnego Nowego Epiru przetrwała bardzo długo ${ }^{67}$. Natomiast stosunkowo nikła wiedza o dyrracheńskich metropolitach, ich sufraganach czy duchownych dygnitarzach, ciaggle utrudnia niestety ustalenie, w jakim stopniu oni sami przyczynili się do budowy statusu swojej metropolii. Problem ten wydaje się stanowić jedno z wyzwań stojących przed badaczami średniowiecznych dziejów Kościoła prawosławnego na ziemiach dzisiejszej Albanii.

\section{THE BISHOPS OF DYRRACHION IN THE ORGANIZATION STRUCTURES OF THE PATRIARCHATE OF CONSTANTINOPLE: THE $7^{\mathrm{TH}}-11^{\mathrm{TH}}$ CENTURIES}

\section{(Summary)}

The Early Middle Ages brought grave losses to the Christian Churches in the East. It was only the patriarchate of Constantinople that managed to maintain its previous dignity. Starting form the end of the $7^{\text {th }}$ century, one may notice the patriarchate activity in the western Balkans. That church substance, having survived barbarians invasion, was defined in the literature as ,the bridge between the West and the East" and it became the subject matter of a rivalry with the papacy. The patriarchate of Constantinople, consistently supported by the emperors of the New Rome, gradually gained superiority in this field. A significant role in these changes was played by the attitude of the patriarchate towards the bishopric in Dyrrachion (at present Dürres in Albania). The majority of preserved written sources concerning this church centre was created in a defined relationship with projects pursued by some emperors and patriarchs. From this perspective, one may follow the evolution of the local bishopric status based on preserved registers of bishoprics subject to Constantinople (Notitiae episcopatuum Ecclesiae Constantinopolitane) as well as the lists of attendance of Dyrrachion's metropolitan bishops at the Trullan Synod (692) and The Second Council of Nicaea (787). In the first case, it is possible to reconstruct the image of the mediaeval Dyrrachion metropolis clearly referring to the ancient church traditions of the New and Old Epirus (Epirus Vetus i Epirus Nova). However, the second preserved source data collection underlines quite high status of the bishops of Dyrrachion at synods and councils, which re-

${ }^{67}$ Przetrwała nawet czasy bizantyńskie i pierwsze trzy stulecia panowania osmańskiego. Kiedy w 1767 r. nastapiła likwidacja arcybiskupstwa bułgarskiego, jego zachodnie eparchie wraz z Ochrydą przyłączono do metropolii dyrracheńskiej, która w ten sposób objęła swą jurysdykcją ziemie porównywalne z obszarem wytyczonym przez wykaz biskupstw z poł. VIII w., por. И. Снегаровъ, История на Охридската архиепископия-патриаршия, t. 2: Отъ паданетой подъ туричте до нейното унищожение (1394-1767 г.), София 1995 [reprint wydania z r. 1932], 149-150, 174, 176 i $222-224$. 
flects their growing position (in comparison with Thessaloniki, Corinth or Athens) in the organization structures of the patriarchate of Constantinople. 